\title{
Comparative Studies on Different Methods of Estimation of Electrical Conductivity in Groundnut
}

\author{
A. Suganthi ${ }^{1 *}$ and P. Selvaraju ${ }^{2}$ \\ ${ }^{1}$ Department of Seed Science and Technology, Tamil Nadu Agricultural University, \\ Coimbatore-3, Tamil Nadu, India \\ ${ }^{2}$ Seed Centre, Tamil Nadu Agricultural University, \\ Coimbatore-3, Tamil Nadu, India \\ *Corresponding author
}

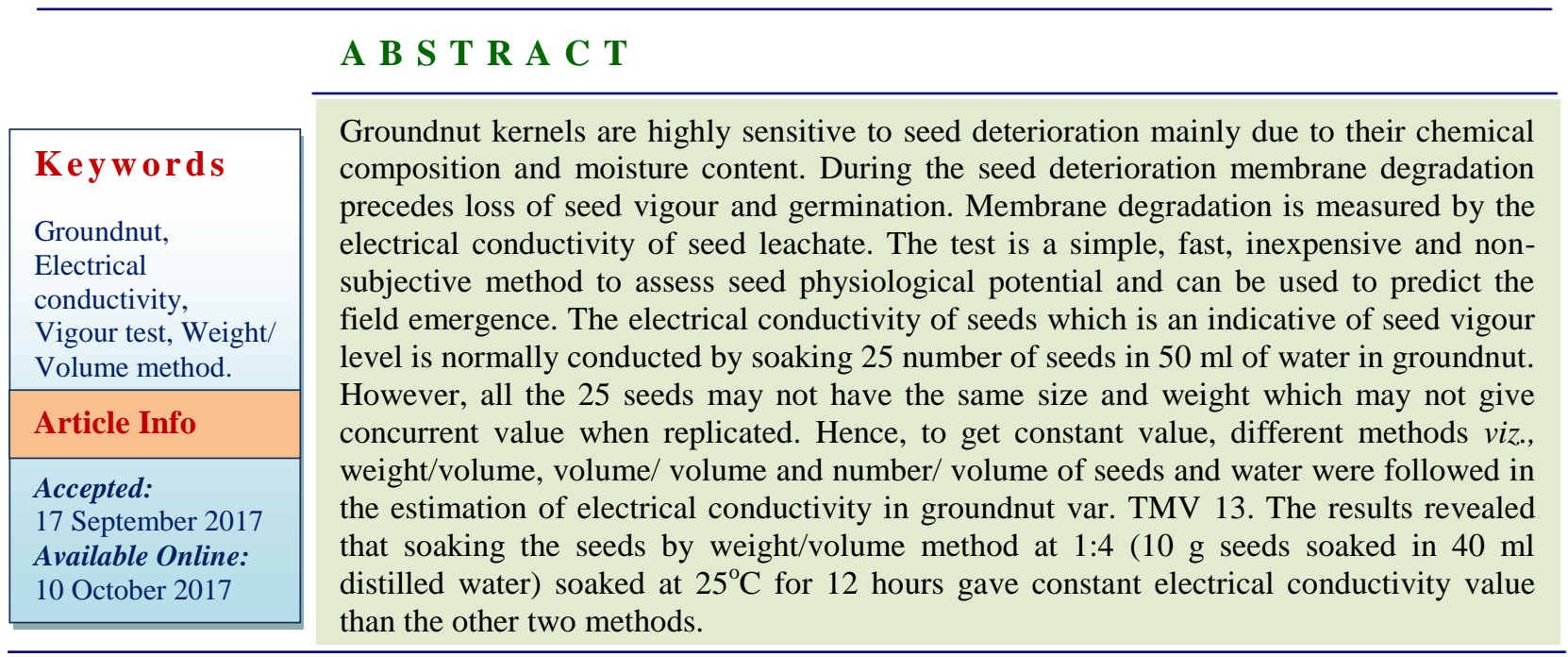

\section{Introduction}

Availability of quality seed is one of the major constraints for increasing the productivity of groundnut. Groundnut (Arachis hypogaea L.) is an important legume oilseed crop in about 100 countries in the subtropical and tropical regions. The high oil content in groundnut seeds (45 - 55\%) makes it more perishable and prone to rapid quality deterioration and loss in viability (Perez and Arguello, 1995).

Membrane integrity degradation is one of the primary causes for seed viability deterioration.
The electrical conductivity test evaluates the degree of structure of the cell membranes due to the deterioration of the seeds, by determining the amount of leached ions in imbibition solution.

Seeds with lower physiological potential release higher amounts of leachate, as a consequence of the lower structuring and selectivity of the membranes (Vieira and Krzyzanowski, 1999). But, high vigour seeds re-establish the membranes at the faster rate with subsequent less leakage. 
The first vigour test included in the International Rules for Seed Testing of ISTA was the electrical conductivity test for garden peas (Pisum sativum L.) in 2001. Currently, ISTA Rules (ISTA, 2014) recommend this test for garden peas, field beans (Phaseolus vulgaris L.) and soybeans [Glycine $\max$ (L.) Merrill]. The electrical conductivity vigour test is a simple, fast, inexpensive and nonsubjective method to assess seed physiological potential and can be used to predict the field emergence. The conductivity test provides a measurement of electrolyte leakage from plant tissues and was first recognized by Hibbard and Miller (1928). It was later developed into a routine vigour test to predict field emergence of garden pea (Matthews and Bradnock 1967).

Farmers and seedsmen require the information to quickly determine the expected rapidity and uniformity of seedling emergence when purchasing seeds. Because they are aware that loss in vigour precedes loss in viability. Electrical conductivity test is a promising vigor test since, it produces fast results $(<24 \mathrm{~h})$. These tests are not affected by seed dormancy, do not require sophisticated equipment or highly skilled personnel and they could be used to shorten the decision period in the seed industry management (Silva et al., 2013). More factors are affecting electrical conductivity test viz., seed size (Tao, 1978; Deswal and Sheoran, 1993), soaking temperature (Murphy and Noland, 1982), soaking period (Loeffler et al., 1988; Schmidt and Tracy, 1989), initial water content (Tao, 1978; Loeffler et al., 1988; Vieira et al., 2002), and the presence of physical damaged seeds (Tao, 1978; Duke and Kakefuda, 1981). However, all these factors can be controlled to minimize their effects. Besides, there is another group of factors which cannot be easily controlled, such as the effect of genotype (Short and Lacy, 1976; Panobianco and Vieira, 1996), seed developmental stage at harvesting (Styer and Cantliffe, 1983; Powell, 1986) and storage conditions (Ferguson, 1988; Vieira et al., 2001).

With this background, the present investigations were carried out to determine the accurate method for the estimation of electrical conductivity in groundnut seeds.

\section{Materials and Methods}

The laboratory experiment was conducted at Department of Seed Science and Technology, Tamil Nadu Agricultural University, Coimbatore during 2016 - 2017. The freshly harvested pods of groundnut var. TMV 13 were collected from Villupuram. The collected samples were hand sorted and cleaned thoroughly.

Before conducting the experiment, the seed moisture content was determined by low constant temperature method (ISTA, 2010) on three replicates of five gram seeds each held at $103 \pm 2{ }^{\circ} \mathrm{C}$ temperature for $16 \pm 1 \mathrm{~h}$ and it had been uniform around $10 \%$. The kernels had low moisture content and hence for increasing the seed moisture content, the kernels were added with specified quantity of water using the formula by Gwinner et al., 1996.

The electrical conductivity of distilled water had been less than $5 \mu \mathrm{S} \mathrm{cm}^{-1}$ and was used for the experiment. The water should be stored 24 hours at $25^{\circ} \mathrm{C}$ before conducting the test. In this study, different soaking methods with different seed to water ratio viz., weight/volume method (1:4, $1: 5$ and $1: 6)$, volume/volume method (1:2, 1:3 and 1:4) and number/volume method $(25: 50,25: 75$ and 25:100) along with control (water without seed sample) at the constant temperature of $25^{\circ} \mathrm{C}$ were conducted. To standardize the soaking duration, the electrical conductivity at 
one hour interval upto approximate constant electrical conductivity value was obtained from the leakage.

The electrical conductivity of kernel leachate was measured using Hanna EC 215 multirange bench top conductivity meter. The conductivity of the control was measured and the mean value is subtracted from the readings for the kernel samples. The electrical conductivity of the kernel leachate was expressed as $\mu \mathrm{S} \mathrm{cm}^{-1} \mathrm{~g}^{-1}$.

The experiment was conducted in factorial completely randomized block design and replicated thrice. The data obtained from each of the experiments were subjected to an analysis of variance and treatment differences tested for significance $(\mathrm{P}=0.05)$ as per the methodology described by Gomez and Gomez (1984).

\section{Results and Discussion}

Studies with peanut (Arachis hypogaea L.) (Vanzolini and Nakagawa, 1999b), soybean (Glycine $\max$ (L.) Merrill) (Vieira et al., 2002), corn (Zea mays L.) (Fessel et al., 2006) and cowpea (Vigna unguiculata (L.) Walp.) Dutra et al., 2006) seeds have shown that the electrical conductivity test is suitable for evaluating a seed lot's vigour. Membrane disruption is one of the primary reasons attributed to seed deterioration. Electrical conductivity test measures the amount of electrolytes released by the seeds during soaking, which is related to the integrity of cell membranes (Mathews and Powell, 1981). The seeds with lower viability leave a greater amount of electrolytes as a consequence of lower cellular membrane stability (Vieira et al., 1999). The factors affecting the electrical conductivity are genotype, seed integrity, size and moisture content as well as soaking period and temperature (Carvalho et al., 2009).

The uniformity of the water content of the seeds is essential for the standardization of the electrical conductivity test (Marcos Filho et al., 1987). In the present study, before conducting the test the seed moisture content should be uniform around $10 \%$ in order to reduce the effect of moisture content for electrical conductivity test. Barbosa et al., 2012 revealed that the groundnut seeds moisture content between $10 \%$ and $14 \%$ before conducting the electrical conductivity test is suitable for electrical conductivity test.

The temperature during soaking may influence the electrical conductivity test. To obtain reproducible results, the temperature should be kept constant during the whole test, and from test to test, as conductivity increases with increasing temperature. However, the temperature of $25^{\circ} \mathrm{C}$ is fairly promising for conduction of this test, since it is closest to the environmental conditions found in majority of the seed testing laboratories.

Fig.1 Standardization of soaking duration and seed to water ratio for electrical conductivity $\left(\mu \mathrm{S} \mathrm{cm}^{-1} \mathrm{~g}^{-1}\right)$ test in Groundnut var. TMV 13 by weight/volume method

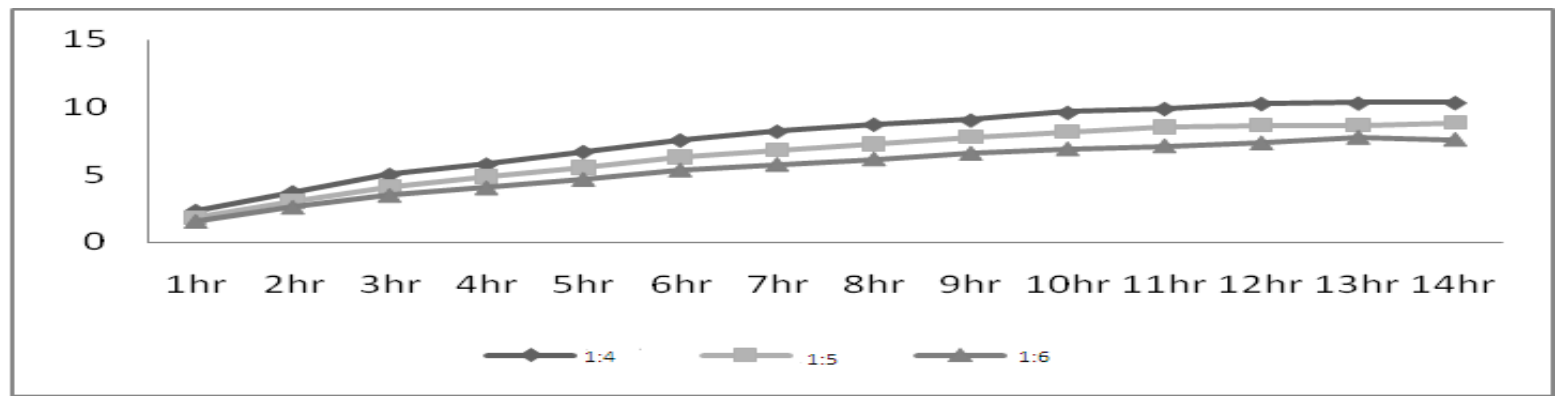


Fig.2 Standardization of soaking duration and seed to water ratio for electrical conductivity $\left(\mu \mathrm{S} \mathrm{cm}^{-1} \mathrm{~g}^{-1}\right)$ test in Groundnut var. TMV 13 by volume/volume method

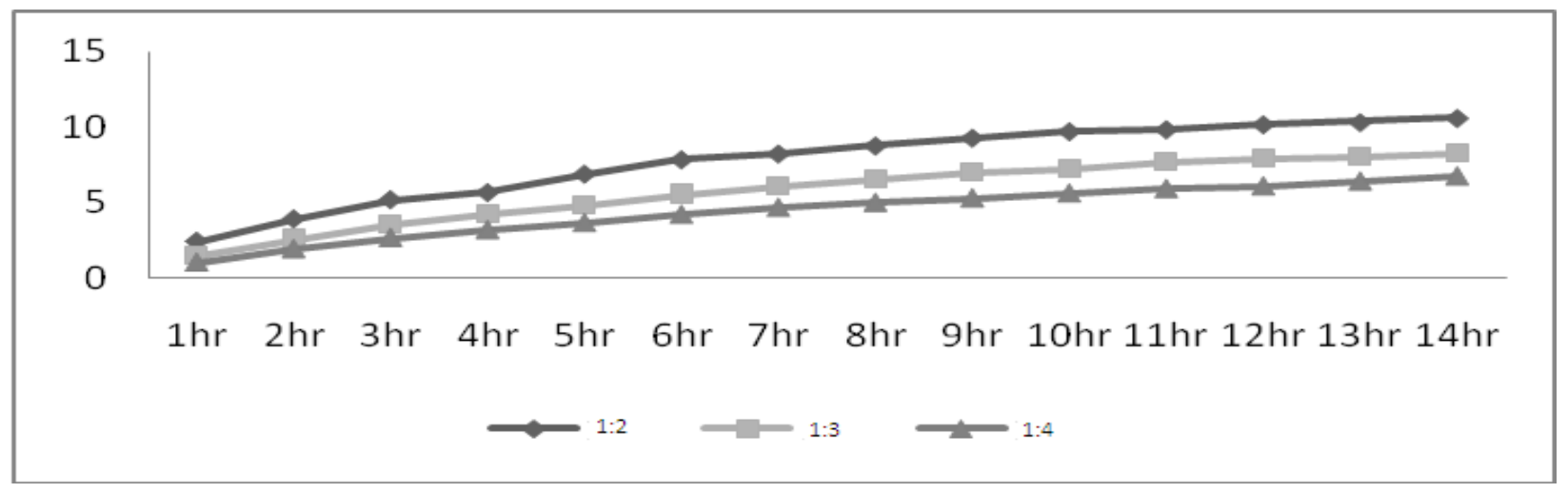

Fig.3 Standardization of soaking duration and seed to water ratio for electrical conductivity $\left(\mu \mathrm{Sm}^{-1} \mathrm{~g}^{-1}\right)$ test in Groundnut var. TMV 13 by number/volume method

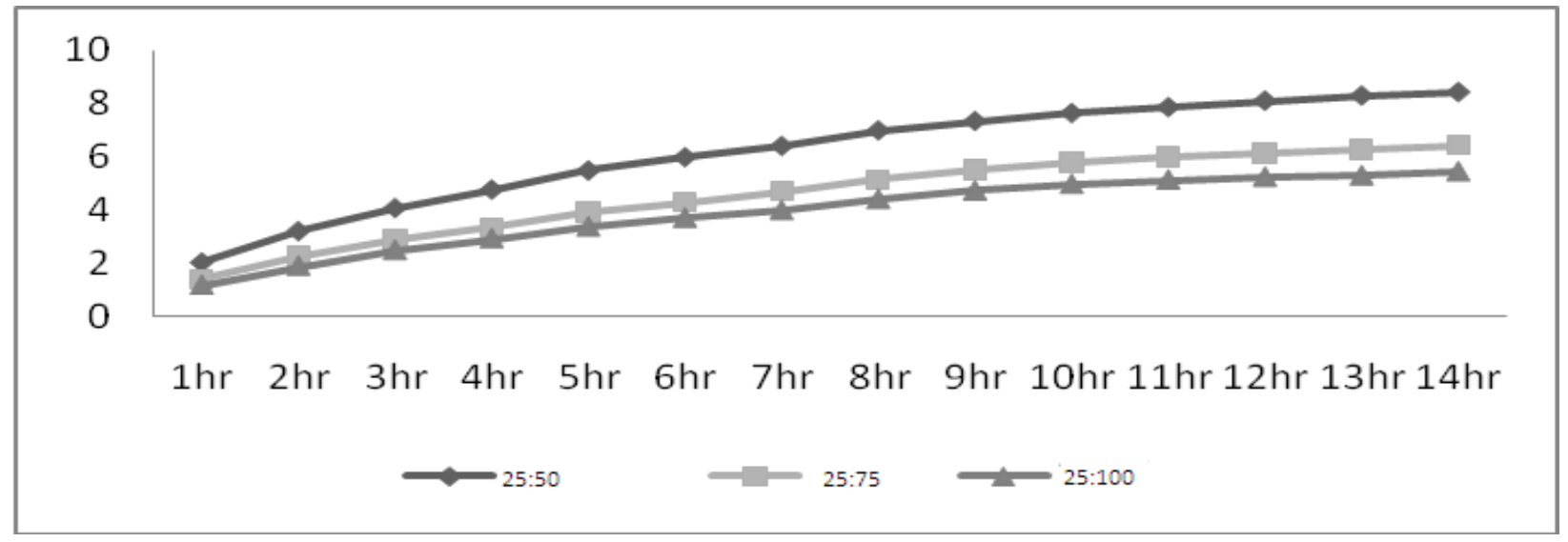

In the present study, weight/volume method gave constant electrical conductivity value compared to other two methods. The electrical conductivity of seeds which is an indicative of seed vigour level is normally conducted by soaking 25 numbers of seeds in $50 \mathrm{ml}$ of water in groundnut. However, all the 25 seeds may not have the same size and weight which may not give concurrent value when replicated. Prete (1992) obtained high electrical conductivity values for seeds from the smallest sieve compared to large sieve due to either a more advanced deterioration stage or a greater degree of immaturity in this size class. Tao (1978) and Loeffler et al., 1988 reported that the electrical conductivity results be expressed on a weight basis $\left(\mu \mathrm{Sm}^{-1} \mathrm{~g}^{-1}\right)$, in order to reduce the effect of seed size for electrical conductivity test in soybean seeds. In the present study, the number/volume method did not obtain approximate constant electrical conductivity value upto 14 hours after soaking due to different seed weight.

In the present study, weight/volume method with 1:4 seed to water ratio and volume/ volume method with 1: 2 seed to water ratio showed approximate constant electrical conductivity value after 12 hours of soaking. In pea and soybean seeds, the electrical conductivity test has been conducted with seed soaking in water for 24 hours, as it is a suitable period for the routine of seed analysis laboratories (Dias and Marcos Filho, 1996) 
(Figs. 1-3). However, several studies have indicated the possibility of using shorter periods for bean and pod seeds (Dias et al., 1998), peanut (Vanzolini and Nakagawa, 2005) and zucchini seeds (Dutra and Vieira, 2006). The possibility of reducing this period is advantageous for the seed industry, since it facilitates faster decision making regarding the management of lots. In addition to the soaking period, Vieira and Krzyzanowski (1999) stated that the volume of water may affect the test results. Dutra and Vieira (2006) observed a reduction of the electrical conductivity values obtained with $75 \mathrm{ml}$ of water compared to those obtained with $50 \mathrm{ml}$, which is related to the leaching effect.

It could be concluded that among the different seed to water ratio methods, weight/volume method at 1:4 (10 g seeds soaked in $40 \mathrm{ml}$ distilled water) soaked at $25^{\circ} \mathrm{C}$ for 12 hours is an accurate method for the estimation of electrical conductivity in groundnut var. TMV 13.

\section{References}

Barbosa, R.M., C.B. Silva, M.A. Medeiros, M.A.P.C. Centurion and R.D. Vieira. 2012. Condutividade elétrica em função do teor de água inicial de sementes de amendoim. Ciência Rural 42(1):45-51.

Carvalho, L.F.D., C.S. Sediyama, D.C. Fernandes, M.S. Reis and M.A. Moreira. 2009. Rapid test of electrical conductivity and correlation with other tests of vigor. Rev. Bras. Seeds, 31(1).

DeswaL, D.P., and I.S. Sheoran. 1993. A simple method for seed leakage measurement: applicable to single seeds of any size. Seed Sci. and Technol., 21:179-185.

Dias, D.C.F.S., A.N. Vieira and M.C. Bhering. 1998. Condutividade elétrica e lixiviação de potássio para avaliação do vigor de sementes de hortaliças: feijão-de-vagem e quiabo. Revista Brasileira de Sementes, 20(2): $408-413$.

Dias, D.C.F.S., and J. Marcos-Filho. 1996.
Electrical conductivity tests to evaluate the vigor of soybean seeds (Glycine $\max$ (L.) Merrill). Scientia Agrícola, 53(1): 1-11.

Duke, S.H., and G. Kakefuda. 1981. Role of the testa in preventing cellular rupture during imbibition of legume seeds. Plant Physiol., 67: 449-456.

Dutra, A.S., and R.D. Vieira. 2006. Teste de condutividade elétrica para a avaliação do vigor de sementes de abobrinha. Revista Brasileira de Sementes, Brasília, 28(2): 117-122.

Dutra, A.S., S.M. Filho and E.M. Teófilo. 2006. Condutividade elétrica em sementes de feijäo caupi (Electrical conductivity of bean seeds). Rev. Ciénc. Agron. 37:166-170.

Ferguson, J.M., 1988. Metabolic and biochemical changes during the early stages of soybean seed deterioration. 138p. Thesis (Ph.D.) University of Kentucky, Lexington.

Fessel, S.A., R.D. Vieira, M.C.P. Cruz, R.C. Paula and M. Panobianco. 2006. Electrical conductivity testing of corn seeds as influenced by temperature and period of storage. Pesq. Agropec. Bras. 41:15511559 .

Gomez, K.A., and A.A. Gomez. 1984. Statistical Procedures for Agricultural Research. John Wiley and Sons, New York.

Gwinner, J., R. Harnisch and O. Müch. 1996. Manuel sur la manutention et al., conservation des grains après-récolte. GTZ, Eschborn, Germany. p 368.

Hibbard, R.P., and E.V. Miller. 1928. Biochemical studies on seed viability I Measurements of conductance and reduction. Plant Physiol., 3: 335-352.

International Seed Testing Association (ISTA). 2010. International Rules for Seed Testing: edition 2010. ISTA, Bassersdorf, Switzerland.

International Seed Testing Association (ISTA). 2014. Seed Vigour Testing. International Rules for Seed Testing, Zurich, Switzerland.

Loeffler, T.M., D.M. Tekrony and D.B. Egli. 1988. The bulk conductivity test as an indicator of soybean seed quality. J. Seed Technol., 12:37-53.

Marcos Filho, J., S.M. Cicero and W.R. Silva. 1987. Evaluation of seed 
quality. Piracicaba: FEALQ, 230p.

Matthews, S., and A.A. Powell. 1981. Electrical conductivity test. In Vigour Test Handbook. (ed. D. A. Perry), pp 37-41, International Seed Testing Association, Zurich.

Matthews, S., and W.T. Bradnock. 1967: The detection of seed samples of wrinkledseeded peas (Pisum sativum L.) of potentially low planting value. Proc International Seed Testing Association 32: 555-563.

Murphy, J.B., and T.L. Noland. 1982. Temperature effects on seed imbibition and leakage mediated by viscosity and membranes. Plant Physiol., 69: 428-431.

Panobianco, M., and R.D. Vieira. 1996. Electrical conductivity of soybean soaked seeds. I. Effect of genotype. Pesquisa Agropecuária Brasileira, 31: 621-627.

Perez, M.A., and J.A. Arguello. 1995. Deterioration in peanuts (Arachis hypogaea (L.)) seeds under natural and accelerated ageing. Seed Sci. Technol., 23: 439 - 445.

Powell, A.A., 1986. Cell membranes and seed leachate conductivity in relation to the quality of seed for sowing. J. Seed Technol., 10: 81-100.

Prete, C.E.C., 1992. Condutividade elétrica do exsudato de grãos de café (Coffea arabica L.) e sua relação com a qualidade da bebida. 1992. 125 f. Dissertação (Mestrado em Agronomia) - Escola Superior de Agricultura Luiz de Queiroz, Piracicaba.

Schmidt, D.H., and W.F. Tracy. 1989. Duration of imbibition affects seed leachate conductivity in sweet corn. Hort. Sci., 24:346-347.

Short, G.E., and M.L. Lacy. 1976. Carbohydrate exudation from pea seeds: effect of cultivar, seed age, seed color, and temperature. Phytopathol, 66: 182-187.

Silva, S.S.D., R.D. Vieira, C.R. Souza Grzybowski, T.C. Carvalho and Maristela
Panobianco. 2013. Electrical conductivity of different common bean seeds genotypes. J. Seed Sci., 35(2): 216-224.

Styer, R.C., and D.J. Cantliffe. 1983. Changes in seed structure and composition during development and their effects on leakage in two endosperm mutants of sweet corn. J. American Society for Hort. Sci., 108:721728.

Tao, J.K., 1978. Factors causing variations in the conductivity test for soybean seeds. J. Seed Technol., 3(1):10-18.

Vanzolini, S., and J. Nakagawa. 1999b. Teste de condutividade elétrica em sementes de amendoim: efeitos de teor de água inicial e de período de embebido (Electrical conductivity test of peanut seeds: effects of initial moisture content and imbibition period). Rev. Bras. Sementes. 21: 46-52.

Vanzolini, S., and J. Nakagawa. 2005. Electricity conductivity test in peanut seeds. Rev. Bras. Seeds, 27(2).

Vieira, R.D., A. Paiva and J.A. Perecin. 1999. Electrical conductivity and field performance of soybean seeds. Seed Technol., 21: 15 - 24.

Vieira, R.D., A.L Penariol, D. Perecin and M. Panobianco. 2002. Electrical conductivity and initial water content of soybean seeds. Pesquisa Agropecuária Brasileira, Brasília, 37(9): 1333-1338.

Vieira, R.D., and F.C. Krzyzanowski. 1999. "Electrical conductivity test," in Seed Vigor: Concepts and Tests, F. C. Krzyzanowski, R. D. Vieira, and J. B. Franc sa Neto, Eds., pp. 4.1-4.26, Abrates, London, UK.

Vieira, R.D., D.M. Tekrony, D.B. Egli and M. Rucker. 2001. Electrical conductivity of soybean seeds after storage in several environments. Seed Sci. and Technol., 29: 599-608.

\section{How to cite this article:}

Suganthi, A. and Selvaraju, P. 2017. Comparative Studies on Different Methods of Estimation of Electrical Conductivity in Groundnut. Int.J.Curr.Microbiol.App.Sci. 6(10): 2038-2043. doi: https://doi.org/10.20546/ijcmas.2017.610.241 